\title{
Kachok Dumpsite Characteristics and Its Future - A Third Kenyan City Perspective
}

Kabok P Aguko*, Michael O Oloko, Stephen G Agong and John Odiaga Oloo

Jaramogi Oginga Odinga University of Science and Technology, Bondo, Kenya

\begin{abstract}
47 Counties inclusive of Kisumu were created as regional administrative units by the Kenyan constitution 2010. The County Government immediately redirected Solid Wastes from other county's townships to be disposed at the existing 2.73 ha Kachok dumpsite. However, the disposal of solid wastes by observation from collection, transportation to dumping has been having challenges. A compelling aim to re-assess the dumpsite arose to determine if it satisfies minimum siting standards, characteristics and potential for the County. Findings show the dump is not properly sited and is at $10 \%$ or lower collection rate of the city's wastes since the 1970's, it is full beyond capacity/potential and a nuisance. The rate indicates need for improved planning, regulation and enforcement for the city and the county. The average dump composition in the order of plastics, glasses and organic matter is $34.7,13.8$ and $51.8 \%$ and weight per volume that varied by depth/age with an estimated volume of $6853 \mathrm{~m}^{3}$. It has high carbon content $(>2 \%)$ and heavy metals have not found their way into the groundwater system. Presence of $\mathrm{NO}_{3}$ though shows groundwater pollution is taking place. Air quality parameters exhibited similar trends with higher concentrations over the dumpsite, reducing outward with the nearby sensitive receptors impacted. The dumpsite should be relocated with caution and use of its organic contents directed to agriculture. The other possible uses such as extraction of energy and recycling of waste contents may need review as dumps depository potential is outlived.
\end{abstract}

Keywords: Dump site; Characteristics; Potential; Agriculture; View point

\section{Introduction}

Solid waste management (SWM) is today undertaken by the City of Kisumu as a delegated responsibility of the County Government of Kisumu (CGK), one of the 47 devolved systems of Governments in the western region of Kenya [1]. The Department of Environment (DOE) carries out the services under sections of; Street Sweeping, Refuse Collection and the Dumpsite Management. Besides, there are Community Based Organizations (CBOs), Non-Governmental Organizations (NGOs) and private companies. Estimates in Kisumu City show that about 35 organizations are involved in sorting at source, collection, transportation, recycling, and creating awareness on SWM. Yet, it is estimated that only about $10 \%$ [2] of the SWs are disposed compared to Nairobi at approximately $40 \%[3,4]$. This activity with the advent of CGK, has been expanded to cover wastes generated in other county County townships (Ahero, Maseno and others) while the main disposal site remains the 2.73 ha at Kachok dumpsite from 1970's. This expansion though is insignificant in extent and characteristics, but has not been properly structured and determined.

Today, the planning and regulation of waste management in Kisumu City is limited and cannot be qualified and quantified appropriately. The unplanned dumping site at Kachok was formalized in the1990's when then the Municipal Council posted employees to attempt some control but with lack of regulation. Government of Kenya outlines the environmental requirements for waste disposal in Kenya were not enacted then [5].

The Kachok dumping started in around 1975 due to increased business within the Kisumu town and that the present Kibuye Market was rejected by the locals as a dumping site. The enhanced business started with the advent of the railroad that reached Kisumu (then port Florence) in 1901. In 1903 the township boundaries were gazetted and in the 1930's and 1940's, the city became a leading East African Centre for military, investment and administration. Some 12,000 acres, including water was thus set aside for its development. It was extended to 53 $\mathrm{km}^{2}$ that included the populated Peri-urban settlements of Manyatta and Nyalenda in 1976. The town is now the third largest in Kenya after Nairobi and Mombasa. Evidence though show that Kachok Dumpsite was reserved for a sisal factory in the 1960's but later for public use as Government Trust Land. Surprisingly, no major thought for future has been devoted to a dumpsite for Kisumu town and the environs and even for Kisumu County to date. This is common in Kenya for the counties and county major towns today.

The city's population on the other hand has grown over the years. At the present growth rate of $4.74 \%$, Kisumu's population is now estimated at 560,000 people. It is characterized by dependant young people; three quarters of who are under 30 and 43.5 percent are under 15 years old. Today, 50\% Peri-urban area houses the highest population density at 10,000 people per $\mathrm{km} 2$, the urban areas at 1,500 to 3,000 people and the rural areas at 170 to 680 people per $\mathrm{km}^{2}$. It covers an area of $297 \mathrm{~km}^{2}$ of land and $120 \mathrm{~km}^{2}$ under the Lake Victoria.

As noted in Khamala EM et al. Nairobi population density at approximately 2.2 million is way above Kisumu City [6]. It is the nearest City for comparison of progress and challenges of SWs management, needless to mention the other African and world cities. No area of Kisumu City today is within the high density range of Nairobi $(>30,000$ people per $\mathrm{km}^{2}$ ). The Kisumu Peri-urban areas population density is only at 10,000 people per $\mathrm{km}^{2}$, which is within the lower range of the Medium density population of Nairobi (5,000 to 29,000 people per

*Corresponding author: Kabok P Aguko, Jaramogi Oginga Odinga University of Science and Technology, Bondo, Kenya, Tel: +0540346828; E-mail: kabpaguko@ yahoo.com

Received: March 30, 2018; Accepted: April 12, 2018; Published: April 19, 2018

Citation: Aguko KP, Oloko MO, Agong SG, Oloo JO (2018) Kachok Dumpsite Characteristics and Its Future - A Third Kenyan City Perspective. Int J Waste Resour 8: 331. doi: 10.4172/2252-5211.1000331

Copyright: ( 2018 Aguko KP, et al. This is an open-access article distributed under the terms of the Creative Commons Attribution License, which permits unrestricted use, distribution, and reproduction in any medium, provided the original author and source are credited. 
$\left.\mathrm{km}^{2}\right)$. The urban areas are still within the low population density of Nairobi $\left(<5,000\right.$ per $\left.\mathrm{km}^{2}\right)$. The question is; at what stage is solid waste management going to be enhanced within Kisumu City and to include Kisumu County. A study was therefore conducted at the dumpsite to determine; the state of the Kachok dumpsite, its material and suitability to minimum standards for Kisumu Town, County and the future. Of great concern, were the volume characteristics of the waste, water flow and water quality, surrounding dynamics, evaluation and way forward.

\section{Materials and Methods}

\section{Dumpsite general characteristics}

Literature review and observation show that in Kenya and most African countries, solid wastes are disposed of by way of open and controlled dumping at designated and non- designated dumpsites [710]. The order in effective control in this case decreases in standards from Cities, towns, townships, village markets and to villages. These can all be observed at the Kachok dumpsite and the Kisumu County.

Dump sites are the most commonly used method for waste disposal in the world [11], Weiss S applies this for Kenya and Kisumu County through observation and records as in Tchobanoglous et al. [12] who states dumpsites are for disposal of solid or semi-solid materials from human and animal activities that are regarded useless, unwanted or hazardous. Visvanathan et al. [13] points out that dumpsites are the easiest option of final disposal in most developing countries-and a matter of transporting the collected waste to the nearest available open space for discharge. Jung et al. [14] notes open dumping to have potential of reducing environmental quality in neighbourhood, poses threat to public health, the environment including scavengers who depend on it for their livelihood. Consequently, the following associated environmental and health hazards and risks which were noted for Kachok by observation and may be experienced continuously [14], in and around many dumpsites in Kachok Waste disposal site [2], and include and not limited to; Unpalatable odour dust emissions, poor aesthetics, environmental nuisances, attraction of vermin, vector and pest, severe health risks to human beings and animal, breeding of disease vectors, flies and rats.

\section{Site physical characteristics}

Apart from the characteristics within and immediately around Kachok dumpsite, the key aspects that are considered for the suitability of dumpsite are capacity and the surrounding location. Ravindra et al. points out the location characteristics that should have been looked at in the case of Kachok dumpsite, but were omitted for reasons of time of initiation [15]. These included and not limited to land use and cover, slope, geology, population projections, soils, distance from roads, rivers, residential areas, airports, canals, lakes and of late in Kenya the community participation. These were reviewed against the present status and the larger overview of the surrounding.

The location characteristics for Kachok Dumpsite as is listed in Ravindra et al. were estimated in a GIS environment [15]. It was noted that Geographic information system (GIS) today is a good decision support tool for planning waste management. Kontos et al. helps in analyzing optimal locations for transfer stations; planning routes for transporting wastes from residential, commercial, industrial customers to holding grounds and to landfills; new locations and monitoring the landfills $[16,17]$. It provides a digital data bank for future monitoring of the site program and reduces time and cost of the site selection. Keir A confirms that initiatives have been taken for example to setup GIS such as ArcInfo and ArcView as key components for managing this information [18]. Republic of Kenya Emphasizes that the trend is towards desk top GIS which has been significantly increasing [19]. Even, ESRI released ArcInfo NT as a substitute to ArcInfo at a workstation. Similarly, many other GIS software vendors have adopted such for example Small World and GenaSys [7].

\section{Dump compaction - height and volume reduction}

The dumpsite characteristics were determined from the surveyed topographic area. Samples were taken at point locations by depth and spread for analysis. The survey was to ascertain topographic area, chemical parameter characteristics, contours, volume of selected sample area (portion) for a compaction test (Figure 1), where use was made of a tractor roller on site.

A reconnaissance (pre-visit) survey was undertaken plus creation of control points for the larger area inclusive of a selected portion. Sport vertical heights were picked at interval of $6 \mathrm{~m}$ and $10 \mathrm{~m}$. The coordinates and point heights were booked for determination of volume and area in the two cases, before and after compaction. The selected area was for determining the effectiveness of onsite use of the tractor roller in compaction.

The Total Station survey equipment and the TopoCAD (software) were used for picking the boundary of the plot, vertical heights and for plotting the field data $(\mathrm{x}, \mathrm{y}, \mathrm{z})$. The data were for generation of contours, area of the plot and for determining the volume of dumped materials above the ground surface. The total volume of the dumpsite was therefore estimated from the compacted select sample area ( $0.77 \mathrm{ha})$ against the total area ( $2.73 \mathrm{ha})$, for assumed density of $450 \mathrm{~kg} / \mathrm{m} 3$ and measured average height or depth of the dump as $6.5 \mathrm{~m}$.

In order to understand the dumpsite chemical characteristics, the shape and depth were taken into account and four locations (A, B, C, D, E) within the dumpsite were selected as in Figure 2. Samples were collected at the locations at different depths from the top to bottom surface of the dumpsite (at $2 \mathrm{~m}, 4 \mathrm{~m}$ and $6 \mathrm{~m}$ ) by use of excavator (sample) scoops from the varied depths. A spade and sack were for collecting the samples from the excavator scoops. The samples were weighed by a spring weighing scale (kgs) and sorted out into; Polythene and Plastics (P/P), Glasses and the organic materials. Each of the sorted

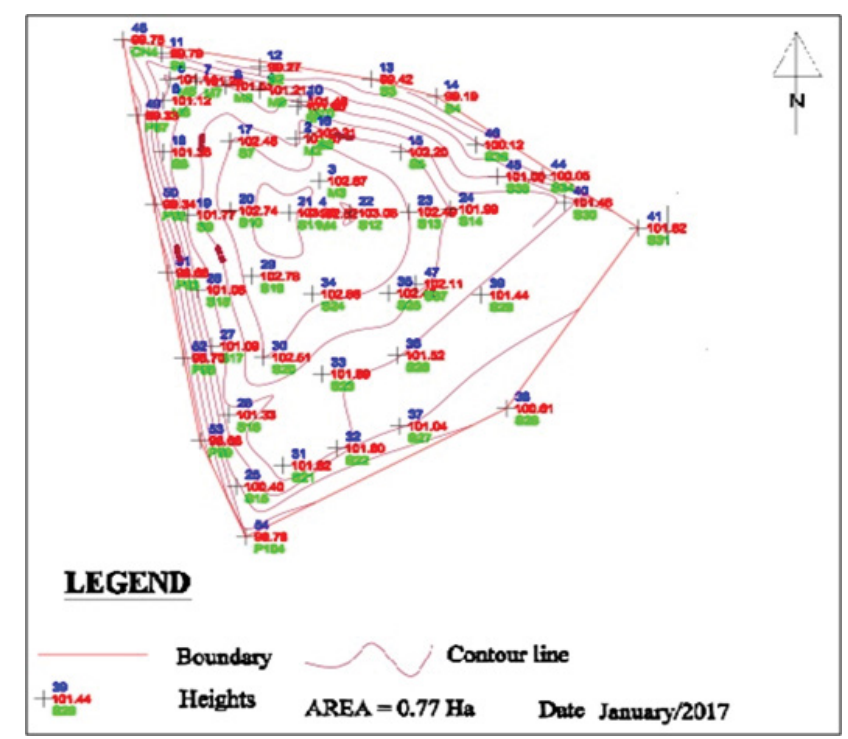

Figure 1: A section of parcel 133, 447 and 448 after compaction. 


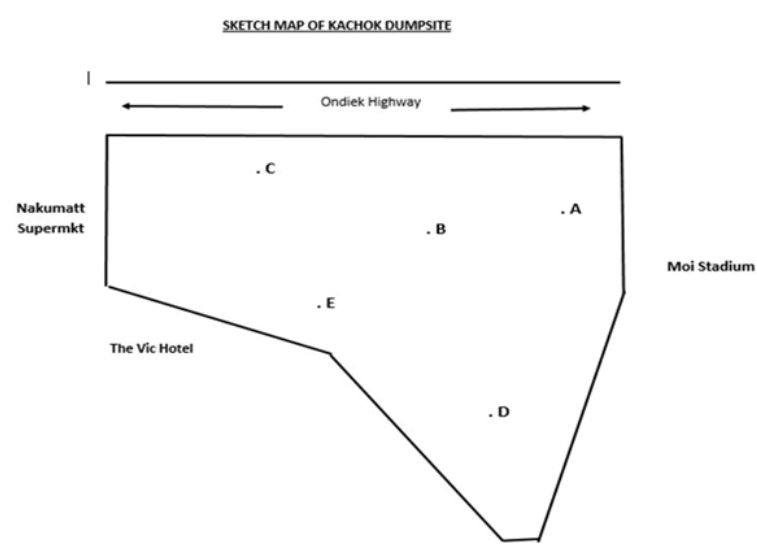

Figure 2: Sampling positions.

materials was individually weighed.

At the predetermined locations and depths as in Figure 2, samples picked were taken for analysis at KALRO Laboratories in Kisumu town for parameters for which reagents were available. The samples were foremost prepared ready for analysis. The basic chemical characteristics determined were; $\mathrm{pH}$ (in water at ratio of 1 sample: 2.5 water); Fe (iron) and $\mathrm{Cr}$ (chromium)-in atomic absorption spectrophotometer (AAS) after extraction using concentrated Sulphuric acid (wet digestion); OC (organic carbon) - using Wakley Black method involving extraction by a mixture of dichromate solution, Phosphoric acid and Sulphuric acid and thereafter titration using ferrous Sulphate.

\section{Dynamics and impact of dumpsite to surrounding}

Hydrology and leachate flow: The effect of Kachok dumpsite on surface water and groundwater bodies was evaluated from samples taken at various points along the drainage channels as in Figure 3. Water samples were taken from a long road side storm drain, the dumpsite, and the channel that partly drains the swamp east of the dumpsite, a spring at Pembe Tatu Estate with origin from the swamp, irrigation canal below the swamp area, Auji stream and a spring within the swampy area. The tests for parameters were guided by the Republic of Kenya [19] and the Kenya Standards KS 05-459, Part 1:1996. Leachate from the dumpsite periodically flows as surface flow into the ditches to Lake Victoria through Auji stream. Three storm water drains surround the dumpsite (Figure 3). The first flows along its northern edge into the main ditch (MA14 - 05 to MA14 - 07). The second runs past the dumpsite (MA14 - 03 to MA14 - 04 to MA14 - 01). The last is the main drainage ditch (MA14 - 09 to MA14 - 08 to MA14 - 02) that joins Auji stream which ends up in Lake Victoria - Kenya. These are enhanced by the ground and surface water often pumped from underground basement spaces of the neighbouring properties in cases of construction and during maintenance operations.

The Kachok dumpsite originally is a borrow pit (E340 $46^{\prime} 10^{\prime \prime}$, S $\left.00^{\circ} 06^{\prime} 21^{\prime \prime}\right)$ which is eastward along Kisumu - Kericho - Nairobi road, about $3 \mathrm{~km}$ from the City Centre (Central Business District). The City is surrounded by Nyamasaria River to the East and Awach River to the west which constitutes the main drain of water flows to Lake Victoria. This system is augmented by Kisat to the west and Auji drainage channels to the east on the inner side of the two major rivers. These rivers are bound in the north eastern side by the Nyangori Nandi hills and Lake Victoria on the south western end. A number

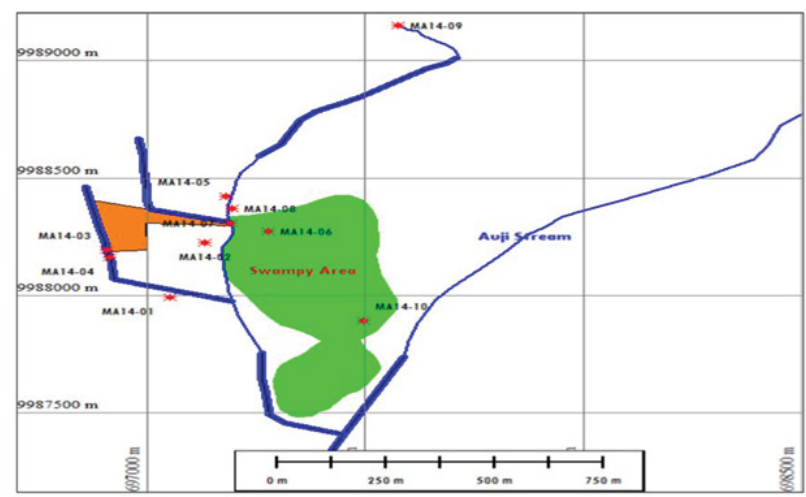

Figure 3: Hydrological features around the Kachok dumpsite.

of constructed drain ditches end up into Auji stream. One such ditch, intimated as perennial in Figure 3, drains the Kachok dumpsite area into an immediate wetland downstream before joining Auji stream.

The flow evaluation was augmented by the K-Conceptual model in a mountain-valley ridge system (Figure 4). According to United Nations Centre for Human Settlements the relative hydraulic conductivity $(\mathrm{K})$ in the valleys in mountainous regions as the case of Kisumu depicts the model in Figure 4. This allows interpretation in the case of Kachok Dumpsite that lies on the peneplain to the Nandi Hills [4]. Figure 4 shows $\mathrm{K}$ in the soil/alluvium layer typically in the range of $10^{-4}$ to $10^{-3}$ $\mathrm{m} / \mathrm{s}$ and extends to about $3 \mathrm{~m}$. This diminishes to $10^{-7}$ to $10^{-5} \mathrm{~m} / \mathrm{s}$ in the saprolite/weathered bedrock horizon, with further reduction to $10^{-9}$ to $10^{-6} \mathrm{~m} / \mathrm{s}$ in bedrock. Groundwater pollution relative to hydraulic conductivity between the various soil horizons (depths) and proximity to the source of pollution hence plays an important role in the Kachok dumpsite risk considerations.

Further, five (5) vertical electrical resistivity soundings tests were undertaken along the Ondiek highway side of the dumpsite to help estimate the thickness and distribution of various soil and lithological horizons. This was done in the direction of MA $14-3$ to MA14 - 4 as in Figure 4. The soil samples previously taken from the dumpsite were analyzed as sample 1 and the last 4 out of 5 samples were aggregated into one for analysis.

\section{Air quality and noise}

The existing background noise levels and air quality were determined in Kachok Waste disposal site from 5 potential noisesensitive receptors identified from reconnaissance survey and use of a GIS map [2], these were;

- ASP1- Centre of the dumpsite (Old Bus Stage ( $0^{\circ} 06^{\prime} 20.9^{\prime \prime} \mathrm{S}, 34^{\circ}$ $46^{\prime} 12.63^{\prime \prime} \mathrm{E}$ as point no 1);

- $\quad$ ASP2 - Perimeter fence opposite of Nakumatt City Supper Market ( $0^{\circ} 06^{\prime} 24.33^{\prime \prime}$ S, $34^{\circ} 46^{\prime} 11.01^{\prime \prime} \mathrm{E}$ as point no 2 );

- ASP3 - River Auji opposite the Kisumu Polytechnic ( $0^{\circ} 06^{\circ}$ $20.75^{\prime \prime} \mathrm{S} 34^{\circ} 46^{\prime} 17.66^{\prime \prime} \mathrm{E}$ as point no 3 );

- $\quad$ ASP4 - Perimeter fence of Makasembo Estate (a residential area, $0^{\circ} 06^{\prime} 09.77^{\prime \prime} \mathrm{S} 34^{\circ} 46^{\prime} 10.42^{\prime \prime} \mathrm{E}$ as point no 4 );

- ASP5 - approximately 100 meters from the Kisumu Day Secondary School ( $0^{\circ} 06^{\prime} 13.69^{\prime \prime} \mathrm{S} 34^{\circ} 46^{\prime} 05.85^{\prime \prime} \mathrm{E}$ as point no 5).

The five sites (Air sampling points - ASPs) selected were taken as; 


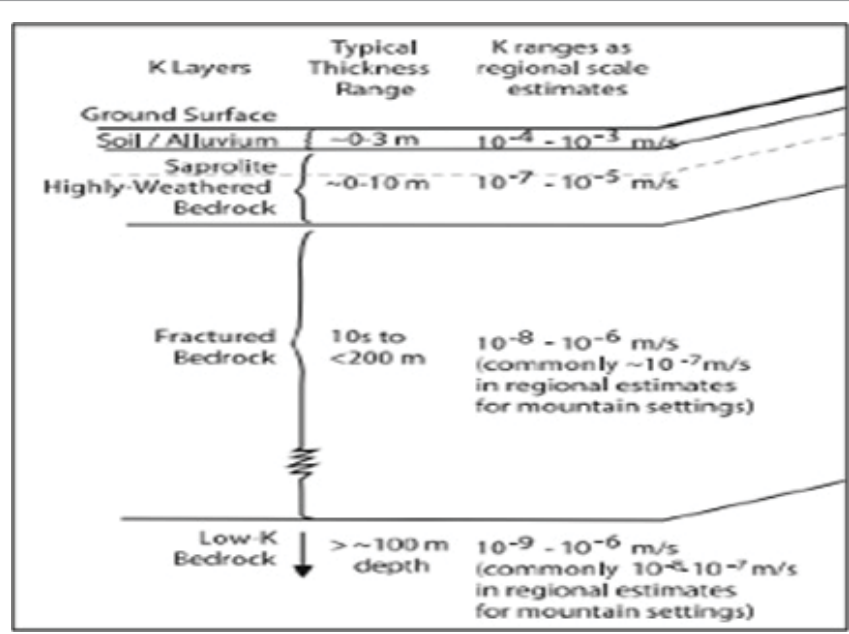

Figure 4: K- Conceptual model in a mountain-valley ridge system.

representative areas of the current noise levels around the dumpsite, easily accessible areas under the current conditions, likely to exist after the improvement or any development of the site and were safe for possible night-time measurements and operations.

The environmental noise assessment was undertaken for additional knowledge apart from air quality in August 2017. This was done by a compliant and calibrated Type 1 data-logging Precision Impulse Integrating Sound Level Meter-LAeq. The basis was the international standards for sound level meter specifications (IEC 61672:1999, IEC 61260:1995 and IEC 60651), together with ISO 19961:2003 and ISO 3095:2001. LAeq is based on the A-weighted sound level and defined in energy as opposed to straight numerical terms. However, the L10 measured against the L90 was also used (ISO 1999, 1990). LAeq is widely used as the base for developing a dose-response relationship for community noise annoyance, and especially where noise is relatively steady and broadband. Apart from being related to the level of exceedance of a guideline value, it gives information regarding nature and extent of the noise source. The L90 gives indication of background noise level, L10 represents higher noise levels and together with L50 and L90 they are used for traffic noise impacts.

The measurements were done over a twenty-four-hour period categorized as daytime (07:00-22:00) and night-time (22:00-07:00) for comparison to international guidelines. In each period the continuous A-weighted equivalent sound pressure level (LAeq) of at least 15-minute duration was taken. Abnormal disturbances, such as loud noise generation in close proximity or sudden noise bursts that affect the measurement, were discarded. In addition to the Leq, L5, L50, and L90, the occurring (Lmax) and (Lmin) levels during the measurement period were also recorded. These were appropriate for determination of; noise levels with future operations; background noise when no activities are contributing to the ambient noise levels; nature and the extent of noise.

The air quality sampling was done by the passive diffusive tubes/ equipment and absorption cartridges for the gases which were mounted in diffusive bodies and exposed for a period of 7 days. Analyses of the cartridges were undertaken at the SGS laboratory in accordance with standard methodologies (Ion chromatography/GCMS). The laboratory data and sampling duration were used for calculating the gases concentrations. Particulate matter samples (TSP, PM10) were done using High Volume Samplers and concentrations determined gravimetrically. Heavy metal analysis was done using ICP/OES (Cold Vapour Technique).

The wind speeds were measured at the five locations with a portable meter also capable of measuring the wind speed gusts. These baseline assessments were for sampling and analysis of all wind directions and for TSPs, $\mathrm{H}_{2} \mathrm{~S}$, PM10, PM2.5, NOx, VOCs, and heavy metals.

\section{Results and Discussion}

The collection and disposal of solid waste today in Kisumu town and environs is the responsibility of Kisumu County government through a department assisted by CBOs, NGOs and individuals under various arrangements. It is estimated that $10 \%$ [2] of wastes is handled compared to $40 \%$ [1], for the capital city of Nairobi. The gap means Kisumu city and the County government need to review and re-direct the SWM intention for future improvement of the system. The key word in this case is proper planning, regulation and enforcement to constantly minimize the gap, Planning need to be for long range to cover every part of the county, which is absent as of now.

\section{Siting of solid waste dump}

Kisumu County is concentrating on solid wastes of Kisumu town and are yet to site and give a comprehensive consideration at village markets, townships, and designated towns and even to Kisumu Town itself. The Kachok dumpsite in terms of its suitability then and now is reviewed against parameters according to Ravindra et al. with the numerical weighting factors as indicated from 1 to 10 [15]. The estimates are; Soils (moderately suitable - 3), Distance to Residential area (unsuitable -1), Distance to Airport (highly suitable - 4), Distance from canals (Unsuitable - 1), Distance from lakes (highly suitable -4), Distance from rivers (unsuitable- 1), Distance from roads (Unsuitable 1), land use/land cover - 2), population density (Unsuitable - 1), Geology (moderately suitable -3 ), Slope (moderately suitable -3 ). Adding the weighting factors and determining the suitability characteristics average $(24 / 12=2)$ according to Government of Kenya, the Kachok dumpsite is categorized between Unsuitable to less Unsuitable [5]. The dumpsite therefore was not suitable from the beginning and should be considered for transfer to another location. The above discussion supports that; i) Kachok dumpsite developed under spontaneity ii) the estimate of handling only $10 \%$ of the waste means a need for large improvement in collection and dumping iii) that the dumpsite size, population growth and quantity of wastes estimates do not matarch.

A number of factors hence need to be considered in any study aimed at identifying or review of location of a specific dumpsite which come into play within such surroundings and villages thereof. These today in Kenya are viewed with challenges of economic, social and political factors as is appropriate. The problem is aggravated by the open nature of disposing waste (dump), Kachok included and especially in the slum areas of most African cities [20,21]. In Kisumu County, apart from the city there are numerous townships and village markets that experience the problem in the glare of exiting existing laws, our stage of development and lack of plans for execution since 1960 and needs to be done.

\section{Dump compaction (height and volume reduction)}

The Kachok Dumpsite at maximum use covers 2.73 hectares confirmed from the topographic survey that included 0.77 ha for the compaction test. The topography of the dump was undulating due to non-uniform treatment of solid wastes as dumping continued. This is in Figure 1 of the topographic map showing concentrated and dispersed contour lines. The average height of the selected area before the survey 
was $101.88 \mathrm{~m}$ above sea level and $100.89 \mathrm{~m}$ after compaction (Table 1). This resulted in an average height reduction of $0.90 \mathrm{~m}$ after compaction (a $68.53 \mathrm{~m}^{3}$ reduction of the 0.77 ha portion of the dumpsite). Out of the survey point heights (45) picked, 19, 12,13,4 and 1 respectively differed in range of change of height after compaction as: $0-0.5 \mathrm{~m}, 0.5-1$ $\mathrm{m}, 1.1-2 \mathrm{~m}, 2.1-3 \mathrm{~m}$ and above $3 \mathrm{~m}$. This indicated that; the tractor roller used a spread and compaction approach in handling the dump wastes, that areas with higher level of dump compacted more compared to the lower level of fresh dump. The potion surveyed was also used in estimating Kachok Dumpsite Volume as;

Compacted sample area $=0.77$ ha (Figure 1), Total area of the dumpsite $=2.73 \mathrm{ha}$, Compacted volume- $6,853 \mathrm{~m}^{3}$ (Estimated from survey - Table 1)

Overall average dumpsite depth $=6.5 \mathrm{~m}$ (estimated from sample digging $3 \mathrm{~m}$ above ground level and $3.5 \mathrm{~m}$ below ground level)

Dumpsite $\mathrm{Vol}=(6,853 \times 2.73) / 0.77 \times 6.5=157,930 \mathrm{~m}^{3} ;$ Assumed Density $=450 \mathrm{~kg} / \mathrm{m}^{3}$ $71,068.5$ tons

Therefore; Weight in tons $=157,930 \times 450=71,068,500=$

\section{Dump main waste types}

Table 2 data show samples taken by weight using a spring balance by depth of the dumpsite as in Figure 2 and named A, B, C, D and E. It is concluded from Table 2 that the plastics percentage on average varied from 12.5 to $48.7 \%$, glass from 6.1 to $51.3 \%$ and organic matter from 5.3 to $68.8 \%$. The average in order of plastics, glasses and organic matter is; $34.7,13.8$ and $51.8 \%$ as is in Table 2 . If outliers in Table 2 are ignored within the columns, the percent plastics, glass and organic matter by depth/location was more or less constant within limits.

In addition, a previous study by Kachok Waste disposal site [2] and by observation within Kisumu City, the type of solid waste (Tables 3-5) delivered to the Kachok dumpsite may be described as mixed municipal waste; basically categorized as domestic, biomedical, industrial, office, supermarket, e - and farm wastes. Out of these; plastics, metals, tins, PET mineral water bottles, glass bottles, paper, e-waste, chicken feed, furniture/wood, polyethylene bags/jute/sacks/polythene bags, food and flimsy plastics materials are often collected for recycling from the Kachok dumpsite.

The Table 5 findings agree with the evaluation of the dump organic matter in Table 2, that it constitute over $50 \%$ of the Dump material, though approach to analysis were different.

These are compatible to what is found in many African cities and includes food, yard, wood wastes, paper, plastic, glass, metal and others; ceramics, textiles, leather, rubber, bones, inerts, ashes, coconut husks, bulky wastes, and household goods.

In terms of agriculture, soil is classified as having high carbon content when organic carbon is greater than $4 \%$ (Table 3 ) and should be applied at a rate of 2.5 tons/ha. The Kachok dump material has high carbon content and can be applied to improve soil to benefit crops conditions. The limits to other elements are as in Table 6 suggested by Riley and Department of Petroleum Resources [22,23]. In the Kachok Sample, the elements were either not detected or are within limits.

Looking at the Table 4 compared to Tables 3 and 6 there are variations. The heavy dangerous metals were either not detected or are within limits (for example Chromium (VI) was not detected). Caution is therefore given that tests should be done from time to time before application in agriculture.

\section{Geology, Leachate Flow, and Soils}

The physical nature of the Kachok dumpsite is as explained in Table 7 as given in perspective implementation suggestions by Kachok Waste disposal site study and Figure 1, in addition to air and noise levels

\begin{tabular}{|c|c|c|c|c|c|c|c|}
\hline Survey Height Points & Comp. Before & Comp. After & Diff. Height & $\begin{array}{l}\text { Survey Height } \\
\text { Points }\end{array}$ & Comp. Before & Comp. (After) & Survey Height Points \\
\hline M1 & 102.44 & 101.66 & 0.78 & P100 & 100.2 & 100.09 & 0.11 \\
\hline M2 & 102.2 & 101.87 & 0.33 & R2 & 101.44 & 100.77 & 0.67 \\
\hline M3 & 101.29 & 100.87 & 0.42 & P17 & 103.16 & 102.66 & 0.5 \\
\hline M4 & 104.05 & 102.52 & 1.53 & $\mathrm{P} 16$ & 102.07 & 100.56 & 1.51 \\
\hline M5 & 103.62 & 101.14 & 2.48 & P15 & 100.14 & 99.92 & 0.22 \\
\hline M6 & 102.14 & 101.12 & 1.02 & $\mathrm{P} 13$ & 102.12 & 101.09 & 1.03 \\
\hline M7 & 101.22 & 100.99 & 0.23 & $\mathrm{P} 124$ & 102.54 & 101.06 & 1.48 \\
\hline M8 & 101.52 & 101.11 & 0.41 & R27 & 103.83 & 102.78 & 1.05 \\
\hline M9 & 101.12 & 100.21 & 0.91 & R18 & 100.84 & 100.23 & 0.61 \\
\hline M10 & 101.45 & 100.46 & 0.99 & R17 & 100.73 & 100.61 & 0.12 \\
\hline P2 & 105.18 & 102.33 & 2.85 & TR 4 & 100.87 & 100.76 & 0.11 \\
\hline P3 & 104.77 & 101.47 & 3.3 & P137 & 100.77 & 100.11 & 0.66 \\
\hline P89 & 104.8 & 102.78 & 2.02 & R24 & 101.67 & 101.44 & 0.23 \\
\hline P90 & 103.97 & 101.06 & 2.91 & P31 & 100.49 & 100.12 & 0.37 \\
\hline P91 & 100.72 & 100.12 & 0.6 & P32 & 102.12 & 100.25 & 1.87 \\
\hline R4 & 104.24 & 103.06 & 1.18 & $\mathrm{P} 140$ & 100.99 & 100.11 & 0.88 \\
\hline R3 & 102.7 & 102.49 & 0.21 & P141 & 100.44 & 100.09 & 0.35 \\
\hline P95 & 102.74 & 101.36 & 1.38 & P139 & 100.68 & 100.16 & 0.52 \\
\hline P94 & 100.53 & 100.12 & 0.41 & S30 & 101.12 & 100.76 & 0.36 \\
\hline R6 & 100.57 & 100.44 & 0.13 & S31 & 101.24 & 100.05 & 1.19 \\
\hline P96 & 102.19 & 101.36 & 0.83 & S32 & 100.76 & 100 & 0.76 \\
\hline P97 & 100.27 & 100.1 & 0.17 & S33 & 101.23 & 100.12 & 1.11 \\
\hline
\end{tabular}


Citation: Aguko KP, Oloko MO, Agong SG, Oloo JO (2018) Kachok Dumpsite Characteristics and Its Future - A Third Kenyan City Perspective. Int J Waste Resour 8: 331. doi: 10.4172/2252-5211.1000331

Page 6 of 11

\begin{tabular}{|c|c|c|c|c|c|c|}
\hline R9 & 102.6 & 101.52 & 1.08 & S34 & 101.55 & 101.11 \\
\hline P102 & 100.58 & 100.44 & 0.14 & S35 & 102.35 & 101.78 \\
\hline P103 & 101.82 & 100.76 & 1.06 & Avg. & 101.88 & 100.98 \\
\hline Area & $0.77 \mathrm{Ha}$ & & Volume & 6.57 \\
\hline
\end{tabular}

Table 1: Determining survey compaction heights.

\begin{tabular}{|c|c|c|c|c|c|c|c|c|}
\hline Site & Depth (m) & G/W (Kg) & $\mathrm{P} / \mathrm{P}(\mathrm{Kg})$ & Glasses $(\mathrm{Kg})$ & Organic $(\mathbf{k g})$ & Plastic \% & Glass $\%$ & Organic $\%$ \\
\hline A1 & 1.8 & 76 & 37 & 5 & 34 & 48.7 & 6.6 & 44.7 \\
\hline A2 & 1.8 & 76 & 33 & 39 & 4 & 43.4 & 51.3 & 5.3 \\
\hline A3 & 1.8 & 80 & 40 & 7 & 33 & 50 & 8.8 & 41.3 \\
\hline B1 & 4 & 48 & 6 & 13 & 29 & 12.5 & 27.1 & 60.4 \\
\hline B2 & 4 & 50 & 17 & 4 & 29 & 34 & 8 & 58 \\
\hline B3 & 4 & 48 & 12 & 3 & 33 & 25 & 6.3 & 68.8 \\
\hline $\mathrm{C} 1$ & 2 & 29 & 9 & 5 & 15 & 31 & 17.2 & 51.7 \\
\hline $\mathrm{C} 2$ & 4 & 29 & 9 & 3 & 17 & 31 & 10.3 & 58.6 \\
\hline $\mathrm{C} 3$ & 6 & 28 & 7 & 4 & 17 & 25 & 14.3 & 60.7 \\
\hline D1 & 2 & 28 & 8 & 4 & 16 & 28.6 & 14.3 & 57.1 \\
\hline $\mathrm{D} 2$ & 4 & 30 & 11 & 3 & 16 & 36.7 & 10 & 53.3 \\
\hline D3 & 6 & 33 & 13 & 2 & 18 & 39.4 & 6.1 & 54.5 \\
\hline E1 & 2 & 32 & 14 & 3 & 15 & 43.8 & 9.4 & 46.9 \\
\hline E2 & 4 & 28 & 12 & 3 & 14 & 42.9 & 10.7 & 50 \\
\hline E3 & 6 & 32 & 9 & 2 & 21 & 28.1 & 6.3 & 65.6 \\
\hline Avg & & 43.1 & 15.8 & 6.7 & 20.7 & 34.7 & 13.8 & 51.8 \\
\hline
\end{tabular}

Table 2: Dump characteristics by location/depth.

\begin{tabular}{|c|c|c|c|c|c|}
\hline Sample ID & Depth (m) & $\mathrm{pH}$ & Fe,ppm & Cr,ppm & OC, $\%$ \\
\hline R1A1 & & 7.3 & 756124.6 & 6136 & 7 \\
\hline R2A1 & & 7.6 & 61607 & 11920 & 6.4 \\
\hline R3A1 & 2 & 7.6 & 73378 & 9206 & 6 \\
\hline R1A2 & & 7.6 & 57296 & 11176 & 7.3 \\
\hline $\mathrm{R} 2 \mathrm{~A} 2$ & & 7.5 & 70433 & 12337 & 5.7 \\
\hline R3A2 & 4 & 7.4 & 58324 & 11538 & 6 \\
\hline R1A3 & & 7.4 & 61862 & 12688 & 6.2 \\
\hline R2A3 & & 7.4 & 51141 & 11523 & 5.2 \\
\hline R3A3 & 6 & 7.5 & 51243 & 11932 & 5.2 \\
\hline R1B1 & & 7.3 & 76877 & 11154 & 4.6 \\
\hline R1B1 & & 7.4 & 61882 & 18846 & 4.5 \\
\hline R2B1 & 2 & 7.2 & 71516 & 14594 & 4.5 \\
\hline R1B2 & & 7.4 & 86395 & 17331 & 4.5 \\
\hline R2B2 & & 7.2 & 62346 & 16175 & 4 \\
\hline R3B2 & 4 & 7.3 & 68358 & 20007 & 4.8 \\
\hline R1B3 & 6 & 7.2 & 87706 & 17674 & 2.9 \\
\hline R1D3 & & 7.4 & 159821 & 18827 & 3.1 \\
\hline R2D3 & & 7 & 81332 & 19262 & 3.1 \\
\hline R3D3 & 6 & 7.3 & 65778 & 22293 & 4.7 \\
\hline R1E1 & & 7.9 & 78637 & 19224 & 4.6 \\
\hline R2E1 & & 7.7 & 70768 & 23115 & 5 \\
\hline R3E1 & 2 & 7.9 & 78757 & 23838 & 4.6 \\
\hline R1E2 & & 7.5 & 63641 & 27738 & 4.6 \\
\hline R2E2 & & 7.6 & 68213 & 23454 & 4.9 \\
\hline R3E2 & 4 & 7.7 & 57003 & 26189 & 3.7 \\
\hline R1E3 & & 7.2 & 73577 & 30334 & 3.9 \\
\hline R2E3 & & 7.1 & 73798 & 30040 & 4.1 \\
\hline R3E3 & 6 & 7.2 & 76419 & 28481 & 4.7 \\
\hline R2B3 & & 7.3 & 159821 & 18827 & 3.1 \\
\hline R3B3 & 6 & 7.2 & 81332 & 19262 & 3.1 \\
\hline R1C1 & & 7.2 & 65778 & 22293 & 4.7 \\
\hline $\mathrm{R} 2 \mathrm{C} 1$ & & 7.3 & 78637 & 19224 & 4.6 \\
\hline
\end{tabular}


Citation: Aguko KP, Oloko MO, Agong SG, Oloo JO (2018) Kachok Dumpsite Characteristics and Its Future - A Third Kenyan City Perspective. Int J Waste Resour 8: 331. doi: 10.4172/2252-5211.1000331

Page 7 of 11

\begin{tabular}{|c|c|c|c|c|c|}
\hline R3C1 & 2 & 7.2 & 70768 & 23115 & 5 \\
\hline R1C2 & & 7.3 & 78757 & 23838 & 4.6 \\
\hline $\mathrm{R} 2 \mathrm{C} 2$ & & 7.3 & 63641 & 27738 & 4.6 \\
\hline $\mathrm{R} 3 \mathrm{C} 2$ & 4 & 7.3 & 68213 & 23454 & 4.9 \\
\hline R1C3 & & 7.2 & 57003 & 26189 & 3.7 \\
\hline $\mathrm{R} 2 \mathrm{C} 3$ & & 7.3 & 73577 & 30334 & 3.9 \\
\hline R3C3 & 6 & 7.2 & 73798 & 30040 & 4.1 \\
\hline R1D1 & & 7.2 & 76419 & 28481 & 4.7 \\
\hline R2D1 & & 7.3 & 73396 & 26906 & 4.3 \\
\hline R3D1 & 2 & 7.2 & 89155 & 30842 & 4.6 \\
\hline R1D2 & & 7.1 & 77158 & 29675 & 4.7 \\
\hline R2D2 & 4 & 7.4 & 83810 & 30364 & 4.5 \\
\hline
\end{tabular}

Table 3: Dump chemical parameter content by depth (KALRO).

\begin{tabular}{|c|c|c|c|c|c|c|c|c|c|}
\hline Parameter- ID/Value & Units & R1D3 & R1D3 & REE1 & R1DB1 & R2A3 & R1/B2/B3 & R3C2 & Test Method \\
\hline Arsenic/As & ppm & ND & ND & ND & ND & ND & ND & ND & AAS \\
\hline Cadmium/Cd & ppm & ND & ND & ND & ND & ND & ND & ND & AAS \\
\hline Calcium & $\mathrm{ppm}$ & 49.73 & Nil & 2651 & Nil & 2290.94 & Nil & 2.66 & AAS \\
\hline Chromium & $\mathrm{ppm}$ & ND & 2.5 & ND & ND & ND & 49.4 & 52.74 & AAS \\
\hline Copper & $\mathrm{ppm}$ & 151 & 585 & 35.2 & 2.24 & 6.53 & 102.92 & 145.57 & AAS \\
\hline Iron & ppm & 4.97 & 9.38 & 1256 & 6.72 & 176.39 & 5.11 & 4.3 & AAS \\
\hline Lead/Pb & $\mathrm{ppm}$ & ND & ND & ND & ND & ND & ND & ND & AAS \\
\hline Mercury/Hg & $\mathrm{ppm}$ & ND & ND & ND & ND & ND & ND & ND & AAS \\
\hline Nickel & $\mathrm{ppm}$ & ND & ND & ND & ND & ND & 20.58 & 25.32 & AAS \\
\hline Potassium/P & $\% \mathrm{~m} / \mathrm{m}$ & 3.2 & Nil & 3.2 & Nil & 2.5 & Nil & Nil & AAS \\
\hline Zinc & $\mathrm{ppm}$ & 621 & 615 & 108 & 590 & 600.5 & 471.39 & 584.4 & ASS \\
\hline
\end{tabular}

Table 4: Kachok dump material parameter analysis (Kenya Bureau of Standards).

\begin{tabular}{|c|c|c|c|c|c|}
\hline Type of Waste & No of Samples & Min $\%$ & Max $\%$ & Mean \% Composition & Consist of water bottles, and any high density plastic materials \\
\hline Plastic & 20 & 2.86 & 15.15 & 9 & Consist of low density polythene papers like those used in packaging at \\
supermarkets
\end{tabular}

Table 5: Percentage composition of Kachok dumpsite waste.

\begin{tabular}{|c|c|c|c|c|c|}
\hline \multirow{2}{*}{ Element } & \multirow{2}{*}{ Unit } & \multirow{2}{*}{ Value in O.M } & \multicolumn{2}{|c|}{ Limits in $\mathbf{m g} / \mathbf{k g}$} & \multirow{2}{*}{ Test method } \\
\hline & & & Department of Petroleum Resources [23] & Riley RG et al. [22] & \\
\hline Arsenic/As & ppm & ND & - & - & AAS \\
\hline Cadmium/Cd & ppm & ND & 380 & 100 & AAS \\
\hline Calcium & ppm & 713.48 & - & - & AAS \\
\hline Chromium & ppm & 14.95 & 240 & 100 & AAS \\
\hline Copper & $\mathrm{ppm}$ & 146.92 & 10 & - & AAS \\
\hline Iron & ppm & 208.98 & - & - & AAS \\
\hline Lead/Pb & ppm & ND & 210 & 600 & AAS \\
\hline
\end{tabular}


Citation: Aguko KP, Oloko MO, Agong SG, Oloo JO (2018) Kachok Dumpsite Characteristics and Its Future - A Third Kenyan City Perspective. Int J Waste Resour 8: 331. doi: 10.4172/2252-5211.1000331

Page 8 of 11

\begin{tabular}{|c|c|c|c|c|c|}
\hline Mercury/Hg & ppm & ND & 530 & AAS \\
\hline Nickel & ppm & 6.56 & 720 & - \\
\hline Potassium $/ \mathrm{K}$ & $\% \mathrm{~m} / \mathrm{m}$ & 1.27 & - & AAS \\
\hline Zinc & $\mathrm{ppm}$ & 512.89 & - & AAS & AAS \\
\hline
\end{tabular}

Table 6: Permissible element limits in soil for crop growth.

\begin{tabular}{|c|c|}
\hline Type of Soil Layer & Description \\
\hline Surface Layer & Often <1 m thick \\
\hline Lateritic horizon & $\begin{array}{c}\text { Gavel in varying stages of weathering; mixed with decaying solid waste and is generally <5 metres deep. } \\
\text { extends to } 10 \text { metres on average. This is the receptor to leachate and immobilizes salts of the groundwater; horizon is } \\
\text { generally }<5 \text { ohm-m, }\end{array}$ \\
\hline highly weathered laterite & $\begin{array}{c}\text { Varies in thickness across dumpsite due interplay of physical and chemical processes on the rock. Vary from } 1 \mathrm{~m} \text { to at least } \\
10 \mathrm{~m} \text { thick and is water-bearing to as deep as } 30 \text { metres underground }\end{array}$ \\
\hline $\begin{array}{c}\text { Saprolite - weathered layer } \\
\text { Phonolite bedrock - Unweathered to slightly } \\
\text { weathered }\end{array}$ & $\begin{array}{c}\text { Runs on the north-south plane and forms the impermeable layer (aquitard) at the base of the shallow aquifer; porphyritic } \\
\text { phonolite from } 10 \mathrm{~m} \text { to } 30 \mathrm{~m} \text { below ground level. The net result is groundwater flows in a south-easterly direction from the } \\
\text { dumpsite. }\end{array}$ \\
\hline
\end{tabular}

Table 7: Soil layers at Kachok dumpsite.

within and around the dumpsite [2].

Based on the vertical electrical resistivity soundings tests along the Ondiek highway the bedrock returned high resistivity at some locations thus indicating it is unweathered and generally unfractured. It demonstrates that there is no solute/leachate transport taking place in the zone and all seeps remain in situ. Thus, the bedrock zone described in Table 7 had the lowest vulnerability to pollution.

The results of analysis of the soil under the dump site as in Table 8 shows concentration of inorganic toxicants in a descending order, Though parameter concentration of groundwater from proximity of the dumpsite were found to be within permissible limits except $\mathrm{Fe}$ and Mn (Table 8). This suggests that most of the toxicants are retained in the soil and do not find way into the groundwater system. It also confirms that the dumping of hazardous materials such as batteries $(\mathrm{Zn}, \mathrm{Pb})$ and fluorescent lamps $(\mathrm{Zn})$ have been taking place evidenced by the site samples tested. Test on the Dump material as in Tables 3 and 4 confirms presence of the metals found in the soil of Kachok Waste disposal site as in Table 8, though the magnitude differs [2].

\section{Leachate flow}

Overall, there is no widespread occurrence of heavy metals, organic constituents or pesticides in surface water. But later tests in Table 3 indeed indicate high level of organic content of the dumpsite materials.

Underneath the dump wastes, the vertical component of flowing water transports the leachate and the dissolved toxicants to the vadose zone ( 2 meters thick) into the groundwater zone $(2.5-3 \mathrm{~m})$. The deeper regional flow however is south-westward in the direction of Lake Victoria, about 25-30 metres below ground level at the bed rock. From KALRO and KBS dump material analyses (Tables 3 and 4) together with Kachok Waste disposal site study [2], (Tables 8 and 9), it is observed that there is;

o Significant presence of heavy metal toxicants in the soil at the dumpsite.

o Minimal evidence of heavy metal presence in groundwater at locations beyond the dumpsite.

o The surface water is affected by organic contaminants and heavy metals as in Table 9.

o The water flow direction is generally in the west direction

\begin{tabular}{|c|c|c|}
\hline Parameter & Sample 1 $\mathbf{( m g} / \mathbf{k g})$ & Sample 2, 3, 4, 5 $\mathbf{~ m g / k g )}$ \\
\hline Iron & 33212.8 & 33199.1 \\
\hline Manganese & 5510.23 & 7970.55 \\
\hline Zinc & 214.18 & 447.52 \\
\hline Copper & 144.37 & 118.25 \\
\hline Lead & 80.67 & 43.63 \\
\hline Chromium & 22.02 & 23.42 \\
\hline Nickel & 12.26 & 11.85 \\
\hline Cadmium & 10.09 & 9.62 \\
\hline Arsenic & 6.27 & 9.01 \\
\hline Beryllium & 2.56 & 2.56 \\
\hline Mercury & $<0.005$ & $<0.005$ \\
\hline
\end{tabular}

Table 8: Values of heavy metal toxicants in soil.

from drain (MA14 -05, 08, 07, 02) to drain (MA14 -05, 08, 07, 02) and to swamp area (MA14 -06 and 10) (Figure 4).

Some of the sample results as in Table 9 show concentrations above permissible levels for some parameters, Total coliforms; E. coli; BOD; COD; Nitrates; TDS; Iron; Chromium and Manganese. Thus, $\mathrm{NO}_{3}$ is generally above the guidelines in all cases except one. BOD is high in one case and above by $50 \%$ of guideline in all other cases. COD are high in two cases and also above by $50 \%$ of the guidelines in all other cases. TDS is above guideline in 5 out of 10 cases and the rest is about $30 \%$ of the guide line. NH4 cases are all significantly below the guideline. As for organisms (Total coliforms and E. coli) all the sites showed TNTC except at site 08. Apart from Fe and Mn the rest of metals tested in Table 9 are all below the guideline.

It is noted that; the leachate flow was because of significant secondary permeability of the rock below the horizon (Figure 4) that was conducive to occurrence of shallow groundwater due to highly weathered laterites and fractured rocks that allowed groundwater movement/storage. The colloids formed thus reduce porosity and enhanced formation of a duricrust, caused by immobilized $\mathrm{Na}+$ in the upper soil layer. This process helped in retaining heavy metals within the dumpsite soil and hence movement into groundwater was restricted. The heavy metals thus apparently have not been finding their way into the groundwater system beyond the dumpsite but held within the soil matrix. The presence of NO3 though shows that groundwater pollution is taking place. 


\begin{tabular}{|c|c|c|c|c|c|c|c|c|c|c|c|c|}
\hline Samp.ID & 01 - canal & 2 well & $\begin{array}{l}-03- \\
\text { storm } \\
\text { drain }\end{array}$ & $\begin{array}{l}-04- \\
\text { storm } \\
\text { drain }\end{array}$ & $-05-$ well & $\begin{array}{c}-06- \\
\text { spring }\end{array}$ & $\begin{array}{l}-07- \\
\text { spring }\end{array}$ & $-08-$ well & $\begin{array}{l}-09- \\
\text { spring }\end{array}$ & stream & Avg. & $\begin{array}{c}\text { Guide value } \\
\text { (mg/l) }\end{array}$ \\
\hline & \multicolumn{12}{|c|}{ Standard: KS 05-459: Part 1:1996 } \\
\hline NO3 & 24.6 & 14.7 & 22.3 & 7.4 & 14 & 0.04 & 38.3 & 47.5 & 27.9 & 10.3 & 20.7 & 10 \\
\hline BOD & 27.7 & 22.8 & 39.44 & 28.75 & 18.25 & 28 & 12.35 & 18.1 & 22.9 & 20.55 & 23.9 & 30 \\
\hline COD & 49 & 41 & 69 & 54 & 31 & 50 & 21 & 32 & 43 & 39 & 42.9 & 50 \\
\hline TDS & 1760 & 567 & 1645 & 336 & 400.4 & 298.5 & 2093 & 1939 & 354 & 1734 & $1,112.70$ & 1500 \\
\hline $\mathrm{NH} 4$ & 0.05 & 0.08 & 0.07 & 0.01 & 0.08 & 0.01 & 0.03 & 0.03 & 0.12 & 0.05 & 0.053 & 0.5 \\
\hline Metals & \multicolumn{11}{|c|}{ Standard: KS 05 - 459 Part 1: 1969} & \\
\hline $\mathrm{Hg}$ & $<0.005$ & $<0.005$ & $<0.005$ & $<0.005$ & $<0.005$ & $<0.005$ & $<0.005$ & $<0.005$ & $<0.005$ & $<0.005$ & $<0.005$ & 0.001 \\
\hline As & ND & ND & ND & ND & ND & ND & ND & ND & ND & ND & ND & 0.05 \\
\hline $\mathrm{Cd}$ & $<0.004$ & $<0.004$ & $<0.004$ & $<0.004$ & $<0.004$ & $<0.004$ & $<0.004$ & $<0.004$ & $<0.004$ & $<0.004$ & $<0.004$ & 0.005 \\
\hline $\mathrm{Pb}$ & $<0.04$ & $<0.04$ & $<0.04$ & $<0.04$ & $<0.04$ & $<0.04$ & $<0.04$ & $<0.04$ & $<0.04$ & $<0.04$ & $<0.04$ & 0.05 \\
\hline $\mathrm{Cu}$ & $<0.006$ & $<0.006$ & $<0.006$ & $<0.006$ & $<0.006$ & $<0.006$ & $<0.006$ & $<0.006$ & $<0.006$ & $<0.006$ & $<0.006$ & 0.1 \\
\hline $\mathrm{Cr}$ & $<0.007$ & $<0.007$ & $<0.007$ & $<0.007$ & $<0.007$ & $<0.007$ & $<0.007$ & $<0.007$ & $<0.007$ & $<0.007$ & $<0.007$ & 0.05 \\
\hline $\mathrm{Zn}$ & $<0.08$ & $<0.08$ & $<0.08$ & $<0.08$ & $<0.08$ & $<0.08$ & $<0.08$ & $<0.08$ & $<0.08$ & $<0.08$ & $<0.08$ & 5 \\
\hline Se & $<0.01$ & $<0.01$ & $<0.01$ & $<0.01$ & $<0.01$ & $<0.01$ & $<0.01$ & $<0.01$ & $<0.01$ & $<0.01$ & $<0.01$ & 0.01 \\
\hline $\mathrm{Mn}$ & $<0.002$ & 1.44 & 2.74 & 5.81 & 0.01 & 2.89 & $<0.002$ & $<0.002$ & 1.98 & 0.01 & & 0.1 \\
\hline $\mathrm{Fe}$ & $<0.007$ & 2.7 & 0.02 & 1.13 & 0.05 & 1.8 & $<0.007$ & $<0.04$ & 0.5 & $<0.007$ & & 0.3 \\
\hline Organisms & \multicolumn{12}{|c|}{ Standard KS $05-200$} \\
\hline T. coli & TNTC & TNTC & TNTC & TNTC & TNTC & TNTC & TNTC & 300 & TNTC & TNTC & TNTC & $100 \mathrm{~m} / \mathrm{l}$ \\
\hline E. coli & TNTC & TNTC & TNTC & TNTC & TNTC & TNTC & TNTC & 40 & TNTC & TNTC & TNTC & $\begin{array}{l}\text { Shall be } \\
\text { Absent }\end{array}$ \\
\hline
\end{tabular}

Table 9: Dump and Surrounding Chemical Parameters

\section{Air quality}

Tables 10 and 11 below show the contributions to ground level concentrations while comparing the United States Environmental protection agency report [24] and WHO report [25] Air Quality Standards for each average period and the pollutant. These are followed by results from the modeling compared to monitoring air quality measuring points assigned by SGS Kenya.

\section{Noise}

As in the Kachok Waste disposal site study, all the noise measured complied with the weather conditions specified by ISO code that is; wind speeds and gusts not exceeding $5 \mathrm{~ms}-1$ and $10 \mathrm{~ms}$-1 respectively [2]. As observed from the 5 monitoring locations and from the baseline noise environment measurements around the dumpsite, the 3 commercial locations (ASP1- 58dB (A), ASP 2-52.2 dB (A), ASP 3-52.4 dB(A)were graded to be within normal limits. The 2 residential areas (ASP $4-57$ $\mathrm{dB}(\mathrm{A})$, ASP $5-58.7 \mathrm{~dB}(\mathrm{~A})$ ) were graded above normal. The results of the grading's were against Kenya's Ambient Noise Regulations as;

- $\quad$ Silent Zone: Daytime: $40 \mathrm{~dB}(\mathrm{~A})$, Night-time: $35 \mathrm{~dB}(\mathrm{~A})$.

- $\quad$ Place of Worship: Daytime:40 dB(A), Night-time $45 \mathrm{~dB}(\mathrm{~A})$.

- Residential; (Indoor) - Daytime $45 \mathrm{~dB}(\mathrm{~A})$; Night-time: 35 $\mathrm{dB}(\mathrm{A})$; (Outdoor)-Daytime: $50 \mathrm{~dB}(\mathrm{~A})$, Night-time: $35 \mathrm{~dB}(\mathrm{~A})$.

- Mixed Residential (with commercial and places of entertainment): Daytime: $55 \mathrm{~dB}(\mathrm{~A})$, Night-time: $35 \mathrm{~dB}(\mathrm{~A})$.

- Commercial: Daytime: $60 \mathrm{~dB}(\mathrm{~A})$, Night-time: $35 \mathrm{~dB}(\mathrm{~A})$.
- World Bank Guidelines (Residential): Daytime: $55 \mathrm{~dB}(\mathrm{~A})$, Night-time: $45 \mathrm{~dB}(\mathrm{~A})$; Industrial: Daytime: 70 .

The noise contour maps were drawn as in Figure 5; wind speeds were mainly SW bound as is in Figure 6, an example of concentrations is as demonstrated by $\mathrm{CH} 4$ in Figure 7.

\section{Conclusion}

Solid waste is a term used variably referring to non-liquid waste materials from domestic, trade, commercial, agricultural, industrial and public activities/services [26]. Ibrahim Identified solid wastes as biodegradable, semi-biodegradable and non- biodegradable materials. Aibor MS et al. [27] generalized solid wastes to comprise domestic and estate solid wastes. Tajudeen I [28] described waste as useless, disused or unused materials that if not properly handled, may be dangerous to the health of man. What is regarded as waste by certain group may be a raw material to another group. However, ESRI [29] emphasizes that solid waste management is a global environmental problem that is significant in today's world and as much in Kisumu city and County.

In the African context, rapid urban growth from the 1960s (Kenya included), has added cumulative pressure on the land resources around the cities, townships, market Centre's and an increase in waste generation. This is no exception for the Kachok Dumpsite of Kisumu City in Kenya. Kachok Dumpsite by its availability was a spontaneous occurrence from rapid population growth and increased prosperity of the town in the early mid-1970's which led to increased waste. Tajudeen I [28] notes, there are factors which influence the choice of a method of waste disposal. Siting therefore differs right from an individual 
Citation: Aguko KP, Oloko MO, Agong SG, Oloo JO (2018) Kachok Dumpsite Characteristics and Its Future - A Third Kenyan City Perspective. Int J Waste Resour 8: 331. doi: 10.4172/2252-5211.1000331

Page 10 of 11

\begin{tabular}{|c|c|c|c|c|}
\hline Pollutant $\left(\mu \mathrm{g} / \mathrm{m}^{3}\right)$ & Averaging Period & Model Results & $\begin{array}{l}\text { United States Environmental } \\
\text { protection agency [24] }\end{array}$ & WHO [25] \\
\hline \multirow[t]{2}{*}{ Particulate Matter (PM10) } & $1-$ hour & 282.49 & ----- & ---- \\
\hline & $24-$ hour & 281 & 150 & 50 \\
\hline \multirow[t]{2}{*}{ Particulate Matter (PM10) } & $1-$ hour & 42.78 & ---- & --- \\
\hline & 24 - hour & 42.55 & 35 & 25 \\
\hline Hydrogen Sulphide (H2S) & $1-$ hour & 0.14 & --- & 10.5 \\
\hline Methane (Ch4) & $1-$ hour & 908.19 & $8,828 \times 103$ & ---- \\
\hline
\end{tabular}

Table 10: Discrete receptors; air dispersion model results.

\begin{tabular}{|c|c|c|c|c|c|c|c|c|}
\hline \multirow{2}{*}{ Pollutant $\left(\mu / \mathrm{m}^{3}\right)$} & \multicolumn{2}{|c|}{$\begin{array}{c}\text { Particulate Matter (PM10) } \\
\text { Value }\end{array}$} & \multicolumn{2}{|c|}{ Particulate Matter (PM 2.5)Value } & \multicolumn{2}{|c|}{ Hydrogen Sulphide $\left(\mathrm{H}_{2} \mathrm{~S}\right)$ Value } & \multicolumn{2}{|c|}{ Methane(CH4) Value } \\
\hline & Measured & Model & Measured & Model & Measured & Model & Measured & Model \\
\hline ASP 1 & 226 & 180.28 & 56 & 27.3 & 0.14 & 0.089 & 918 & 579.59 \\
\hline ASP 2 & 210 & 116.21 & 42 & 17.6 & 0.24 & 0.057 & 579 & 373.62 \\
\hline ASP 3 & 221 & 111.89 & 52 & 16.94 & 0.21 & 0.055 & 904 & 359.72 \\
\hline ASP 4 & 148 & 1.36 & 31 & 0.21 & 0.06 & 0.001 & 235 & 4.36 \\
\hline ASP 5 & 162 & 5.02 & 37 & 0.76 & 0.1 & 0.002 & 228 & 16.15 \\
\hline
\end{tabular}

Table 11: Maximum; air dispersion model results.

livelihood at village (community) level to townships, to designated towns and to cities. Control for whatever reasons for example in a neighborhood seems to be a compelling reason for sitting.

A number of factors hence need to be considered in any study aimed at identifying or review of location of a specific dumpsite which come into play within such surroundings and villages thereof. These are not limited to; location of water resources used for public water supply, land agricultural potential, land use, location of archaeological/historically important sites and areas with mineral rights. These today in Kenya are also viewed with challenges of economic, social and political factors as is appropriate. The problem is aggravated by the open nature of disposing waste (dump), Kachok included and especially in the slum areas of most African cities [10,22]. In Kisumu County, apart from the city there are numerous townships and village markets that experience the problem in the glare of existing laws, our stage of development and lack of plans for execution since 1960 .

The Kachok Dumpsite is an example of many growing cities in Africa where; "Dumping site may be as simple as from a village individual who sees a lot of space and throws anything to a space the eyes can select and the throw potential can accommodate". Kisumu County needs to correct this right from Kisumu City, Townships, and Market Centre's to Villages. This is happening and is continuing to date. It is confirmed that Kachok dumpsite developed under spontaneity as is many in Africa. It handles an estimate of less than $10 \%$ of the waste, meaning there is a need for an enhanced improvement in collection, processing and dumping. The 2.73 ha dumpsite size, population growth and quantity of wastes estimates today do not march. The dump characteristics are also not far off that of the Nairobi City save for quantities and should be the first for considerations in any undertaking of attributes comparisons. There is therefore need for long range planning, regulation and enforcement of waste management in Kisumu City and County. These should be adequately qualified and quantified, as there is lack of data in the SWM.

All the nearby sensitive receptors were impacted by the dumpsite that is Kisumu Day Secondary School, Lutheran Church, Moi Stadium and Nakumatt Mega. As observed from the monitoring locations and from the baseline noise environment measurements, 3 commercial locations were graded to be within normal limits and 2 residential areas were graded above normal. All the key air quality parameters assessed

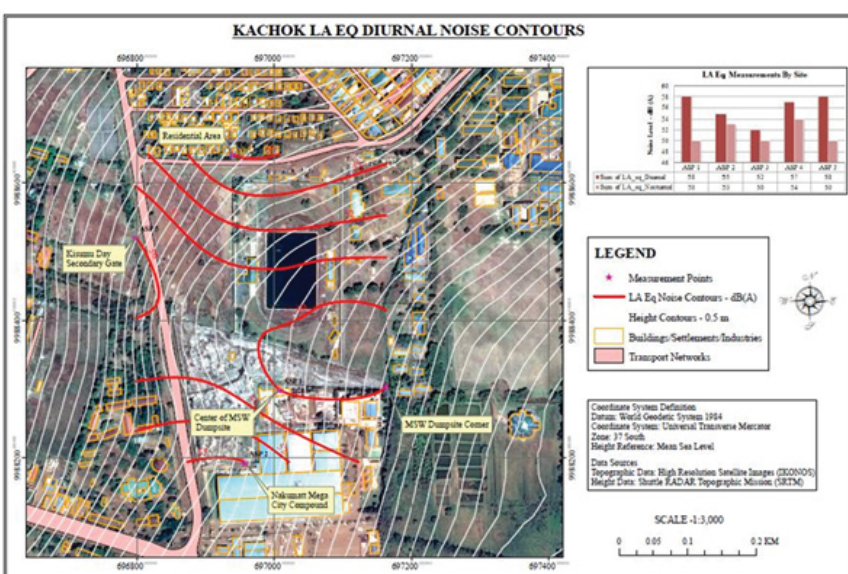

Figure 5: Kachok noice contours.

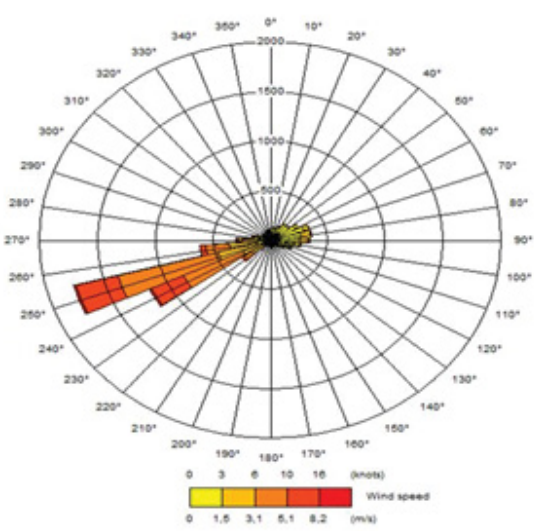

Figure 6: Kachok wind direction. 
Citation: Aguko KP, Oloko MO, Agong SG, Oloo JO (2018) Kachok Dumpsite Characteristics and Its Future - A Third Kenyan City Perspective. Int J Waste Resour 8: 331. doi: 10.4172/2252-5211.1000331

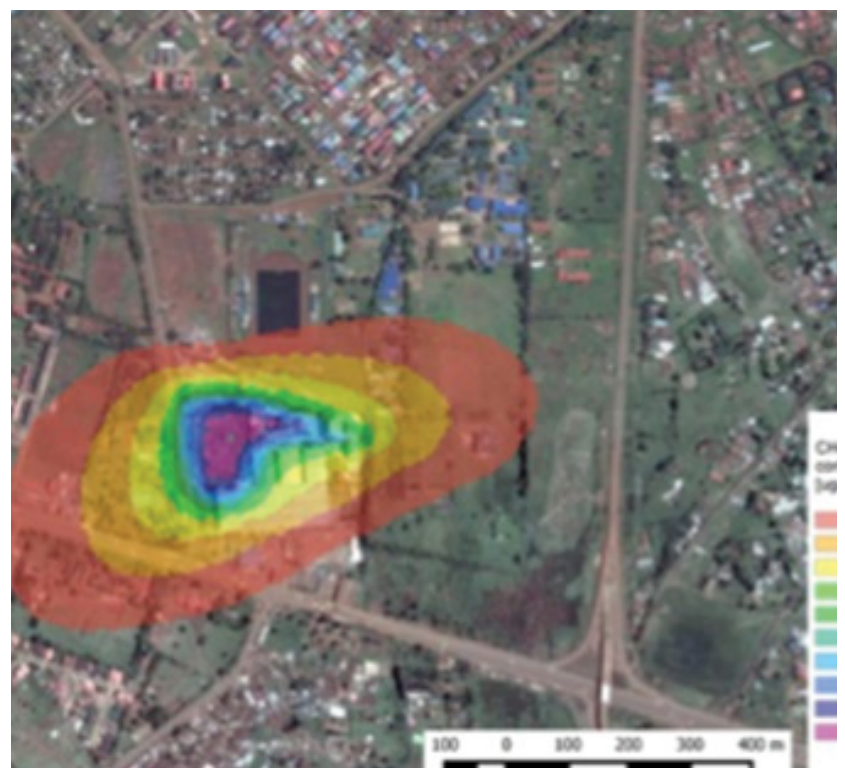

Figure 7: Example map for 1-hour concentrations of $\mathrm{CH} 4$.

exhibited similar trend with higher concentrations (example as Figure 7) over the dumpsite and gradually reducing outward in all directions. It is clear that the dump site has levels of PM10 and PM2.5 that exceeds both the United States Environmental protection agency and WHO $[24,25]$ maximum guideline limit values. Of the air quality parameters $\mathrm{H}_{2} \mathrm{~S}$ and PM10 are the most widespread.

Overall, the Kachok location is not suitable and it is where it is due to its availability. There is no widespread occurrence of heavy metals, organic constituents or pesticides in the surrounding surface water. The heavy metals apparently have not been finding their way into the groundwater system beyond the dumpsite however presence of $\mathrm{NO}_{3}$ shows that groundwater pollution is taking place. Tests of dump material indicates high level of organic content (constitute over 50\%) and can be applied to improve soil to benefit crop conditions. Other possible uses may also be enhanced or initiated, such as extraction of energy, recycling of products but based on improved collection systems and dumping procedures.

\section{Acknowledgment}

The authors acknowledge KLIP, JOOUST, County Government of Kisumu, and the Waste handlers at the Kachok dumpsite.

\section{References}

1. http://kenyalaw.org/kl/index.php?id=398

2. http://www.e-cueassociates.co.ke/index.php/projects/project-series-2-2015

3. Mwaura PM (1991) An assessment of the Management of Garbage Collection and Disposal in Nairobi. Department of Urban and Regional Planning, University of Nairobi.

4. United Nations Centre for Human Settlements (1989) Solid waste management in low-income housing projects: The scope for community participation. Nairobi, Kenya.

5. http://www.kenyalaw.org/

6. Khamala EM, Aganda AA (2013) Municipal solid waste composition and characteristics relevant to the waste -to-energy disposal method for Nairobi city. Global J Engin Design Technol 2: 1-6.

7. Lee GF, Jones LA (1996) Revisions of state MSW landfill regulations: Issues in protecting groundwater quality. Environ Man Rev 29: 32-54.

8. Lee T, Sivapalasundram V (1979) Some aspects of solid waste management in Klang valley. In: Thanh NC (ed.). Paper presented at the Waste Disposal and Resources Recovery. Asian Institute of Technology, Bangkok.

9. Lee $Y$, Krieger L (1990) Landfill site and improvement in design for sanitary landfill in Malaysia. In: Tong SL (ed.). Paper presented at the Hazardous Waste Regulation and Management, Kuala Lumpur. Pp: 175 - 199.

10. Matsufuji V, Sinha K (1990) Landfill site and improvement in design for sanitary landfill in Malaysia.

11. Weiss S (1974) Sanitary landfill technology. Noyes Data Corporation, London.

12. Tchobanoglous G, Vigil SA, Theisen H (1993) Integrated solid waste management. McGraw-Hill, Inc., New York.

13. Visvanathan C, Trankler J (2003) Municipal solid waste management in Asia: A comparative analysis. Workshop on Sustainable Landfill Management.

14. Jung $\mathrm{CH}$, Matsuto T, Tanaka M (2005) Behaviour of metals in ash melting and gasification - Melting of Municipal Solid Waste (MSW). Waste Manag 25: 301 310

15. Ravindra J, Nitin M, Bhalachandra D (2014) Site Suitability for urban solid waste disposal using geoinformatics: A case study of Pune Municipal Corporation Maharashtra. India International Journal of Advanced Remote Sensing and GIS 3: 769-783.

16. Kontos TD, Komilis DP, Halvadakis CP (2005) Siting MSW landfills with a spatial multiple criteria analysis methodology. Waste Management 25: 818-832.

17. Kontos TD, Komilis DP, Halvadakis CP (2003) Siting MSW landfills in Lesvos Island with a GIS-based methodology. Waste Manag Res 21: 262-277.

18. Keir A (1997) The role of GIS in the privatization of Malasia solid waste management. Paper presented at the 6th Ersi South Asia Users Conference Penang, Malasia.

19. Republic of Kenya (2006) Environmental management and co-ordination act: Waste management regulation. Government Printer, Nairobi.

20. Mato RAM (1999) Environmental implications involving the establishment of sanitary landfills in municipalities in Tanzania: The case study of Tanga municipality. Resour Conserv Rec 25: 1-16.

21. Hammer G (2003) Solid waste treatment and disposal: effects on public health and environmental safety. Biotechnology Advances 22: 71-79.

22. Riley RG, Zachara JM, Wobber FJ (1992) Chemical contaminants on DOE lands and selection of contaminated mixtures for subsurface science research US-DOE, Energy Resource Subsurface Science Program, Washington, DC USA.

23. No Authors Listyed (2002) Environmental Guidelines and Standards for the Petroleum Industry in Nigeria (EGASPIN). Department of Petroleum Resources, Nigeria.

24. https://clu-in.org/download/char/epa-600-r-05-123.pdf

25. World Health Organization (2005) Air quality guidelines global update 2005 for particulate matter, ozone, nitrogen dioxide and sulfur dioxide. WHO, Geneva, Switzerland.

26. Ibrahim AM (2002) Introduction to environmental problems and management Kano.

27. Aibor MS, Olorunda JO (2006) A technical handbook of environmental health in the 21st Century for Professional Students.

28. Tajudeen I (2003) Solid waste management strategy in Katsina metropolis: A case study of Katsina Local Government Area. An unpublished undergraduate research project, Bayero University, Kano

29. ESRI (2001) Getting to Know Arc GIS Desktop. 